\title{
正常人のトキソブラスマ抗体保有率について
}

\section{Distribution of Antibodies to Toxoplasma gondii in Norml Human Sera}

\author{
東京医科歯科大学微生物学教室 \\ 清 水 文彥・橋本 雅一・藤田 光一郎・川上省三・小林 勝 \\ 高山正三・吉野 長康・染 矢 博・石川近美・岡本 陽一郎 \\ 増思 悦蔵・武藤 十 郎・甘粕 褛四郎
}

Fumihiko Shimizu, Masakazu Hashimoto, Kôichirô Fujita, Shôzô Kawakami, Masaru Kobayashi Shôzô Takayama, Tsuneyasu Yoshino, Hiroshi Someya, Chikami Ishikawa, Yôichirô Okamoto

Etsuzô Masuda, Jûrô Mutô, Sanshirô Amakasu

Department of Bacteriology, Tokyo Medical and Dental University

\section{I. 緒 言}

トキソプラスマ症の病原体である Toxoplasma gondii は, 1909年 Nicolle et Manceaux ${ }^{13}$ が北アフリカで, ヤマアラシの 1 種 Ctenodactylus gondii から初めて検出 して以来，欧米諸国ではほとんどすべての哺乳類から検 出されたばかりでなく, 鳩, 雀, 鴊等の鳥類から, さら に蛇, 亀, 蛙, 魚類からの検出例が報告され, 日本に捛 いても, 土竜, 狸, 目白, 犬, 猫, 家栄, 鷄, 家鬼等か らの T. gondii の検出例が報告されている。

さらに, 人間に捛いても1939年, Wolf, Cowen and Paige $^{2)}$ が, 脳水腫の乳児から T. gondii を検出した報 告を初めとして, 世界各地で T. gondii の人体感染例が 多数報告され，わが国に抢いても宮川 ${ }^{31}$, 宮崎执よび平 岡 ${ }^{4}$, 松林, 瀬長扢よび田崎 ${ }^{5 / 6)}$ 等が, 人体感染の症例を 報告している。

以上のように, T. gondii は, 人を含めた動物界に広 く存在するととが明らかになつたが, 人間に抒ける検出 例はすべてが乳幼児からのものであつて, 成人からの検 出は末だ 1 例も報告されていない。この点に関して注目 すべき事実は, 最近の血清学的な検索の成績から, $\mathrm{T}$. gondii による不顕性感染が人抢よび動物界にきわめて濃 厚に存在することが指摘され, 殊に成人の場合では, T. gondii に感染しても症状を発現することはきわめて稀て 多くの場合は不顕性感染として存在することが報告され たととである。したがつて, わが国に拉いても T. gondii による不顕性感染の存在が予測されるのであるが,

この T. gondii の不顕性感染の存在に関する研究はい まだきわめて少ない。しかし, T. gondii による感染の 疫学的な解明には, 不顕性感染の存在を明らかにすると
とがきわめて重要なととであると思われる。

このような見地から, われわれは, 成人の T. gondii による不顥性感染の存在执よびその分布状態を明らかに するために, 臨床的に健康と思われる 512名の成人血清 を用いて Sabin and Feldmann の色素試験扣よび補体 結合反灾を用いて血清学的検討を抏てない, 二, 三の知 見を得たのでここに報告する。

\section{II. 実験材料および実験方法}

A. 色素試験 (Sabin and Feldmann 法 ${ }^{7)}$ )

a) 実験材料

i）トキソプラスマ浮遊液：伝染病研究所から分与を 受けた T. gondii RH 株 (マウス累代接種 1,000 代を 超えるもの)を用い, マウス腹腔内接種後 3 日目に $2 \mathrm{ml}$ の生理的食塩水を注入して腹腔液を採取し, 1,000 万〜 3,000 万 $/ \mathrm{mm}^{3}$ の虫体を含む浮遊液をつくり, 腹腔液採 取後 60 分以内に実験に用いた。

ii) Accessory factor：予備実験で合格した正常人血 清を，ドライアイスで凍結保存したものを用いた。

iii）色素試験陽性対照血清：T. gondii の生虫体を用 いて鬼を免疫し, 色素試験で 500〜 4,000 倍の陽性血清 を作製した。

iv）アルカリ性メチレン青溶液： $0.53 \%$ 炭酸ソーダ $9.73 \mathrm{ml}$ と, $1.91 \%$ 硼酸ソーダ $0.27 \mathrm{ml}$ に Merck 製の

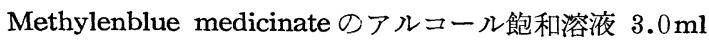
を加えて作製した。な扛本溶液は, 使用の都度新たに調 製した。

v）被検血清：凝固血液示らの分離血清当用い，採血 後 24 時間以内に実験に供した。

b) 実験方法 
i) 予備試験：Accessory factor として用いうる人血 清を選出するために怙てなつた。すなわち，トキソプラ スマ浮遊液 $0.1 \mathrm{ml}$ 《被検人血清 $0.5 \mathrm{ml}$ を加えて混合し たのち, その $0.1 \mathrm{ml}$ に $0.9 \%$ 食塩水 $0.1 \mathrm{ml}$ 加え, $37^{\circ} \mathrm{C}$ の温浴で20分間作用させたのち，アルカリ性メチレン青 溶液 $0.05 \mathrm{ml}$ を加え, トキソプラスマ虫体 100 個を数え, その 95\%以上が染色している血清を Accessory factor として使用した。

ii）本試験：被検人血清を $56^{\circ} \mathrm{C} ， 30$ 分間加熱して非働 性化を抬てない， $0.9 \%$ 食塩水て 4 倍稀釈した血清の $0.1 \mathrm{ml}$ を小試験管にとる別。に,トキソプラスマ浮遊液 と Accessory factor として用いる人血清の原液を 1 : 4 の割に混合し,その $0.1 \mathrm{ml}$ を被検血清稀釈系列に分注 する。ついて，乙の混合液を $37^{\circ} \mathrm{C}$ 温浴で 60 分間作用さ せる。作用後暫時低温 $\left(0 \sim 2{ }^{\circ} \mathrm{C}\right)$ に放置したのち, 再び 室温において，アルカリ性メチレン青溶液 $0.05 \mathrm{ml}$ を各 試験管に加えてょく混合し，ほぼ15分後にその 1 滴を載 せガラス上にとり，440倍の倍率で鏡検する。な持鏡検 は，1 時間以内に終了するょうに注意した。

判定は, 食塩水対照でトキソプラスマ虫体が95\%以上 染色し, また, 陽性鬼血清の所定の濃度で50\%以上の非 染色のトキソプラスマ虫体を示す対照実験の成績が得ら れた場合に㧊いて，虫体 100 個の中，50\%以上の非染色 虫体の存在を示す場合の被検血清の, 最大稀勫度を抗体 価とした。

\section{B. 補体結合反応}

a) 実験材料

i) 抗原の作製：Westphal ${ }^{8}$, Sabin ${ }^{9)}$, 長谷川, 常松 等 ${ }^{10)}$ の方法に準じて抗原を作製した。すなわち，100匹 のマウスの腹腔内に T. gondii を接種し, $3 \sim 4$ 日後に $8 \%$ クェン酸ソーダ夜 $2 \mathrm{ml}$ を注入して採取した腹胿洗 滌液を集める。3,000 r.p.m. 10分間遠心沈溊して得た沈 椬を $50 \mathrm{ml}$ の $3.8 \%$ クエン酸ソーダ溶液に浮遊させ, sonic osillator ( $10 \mathrm{~K}$ cycle, $200 \mathrm{~W}$ ) で 30 60 秒照射して 細胞成分を破壊したのち,再び3,000 r.p.m. 10分間遠心 沈溉を抗てな弓。沈渣を $50 \mathrm{ml}$ の生理的食塩水に浮遊さ せ, 再び Sonic osillator を 20 30分間照射して虫体を 完全に破壊する。この浮遊液に $0.5 \%$ の石炭酸を加え, 氷室に数日〜 1 週間放置したのち，10,000 r.p.m. 60 分間遠心沈澱を扢てない, 得た上清液を抗原液とした。 抗原価の測定は，精製抗原が正常血清との反応で補体結 合反応を示さず，50倍，100倍挔よび 500 倍稀釈免疫血 清と作用させたとき, 補体結合反応陽性であつた抗原稀 釈液に含まれる抗原量を 1 単位とした。この成績から,
精製抗原液の抗原価は毎常40単位前後であつた。

ii）補体：あらかじめ色素試験で完全に陰性であるこ とを確認したモルモット血清を使用した。

iii）感作赤血球：抗緬羊赤血球鬼血清の 3 単位で感作 した $3 \%$ 緬羊赤血球を用いた。

b) 実験方法

アメリカ陸軍々医学校法にしたがつた。すなわち，56 ${ }^{\circ} \mathrm{C}, 30$ 分間加熱した被検血清を生理的食塩水で倍々稀釈 をおこない，それぞれその $0.25 \mathrm{ml}$ を小試験管にとる。 ついて抗原 $0.25 \mathrm{ml}$ ( 4 単位), 補体 $0.5 \mathrm{ml}$ ( 2 単位) を 順次稀釈系列に加えたのち， $37^{\circ} \mathrm{C} て ゙ 60$ 分間作用させる。 作用後， $3 \%, 3$ 単位の感作赤血球浮遊夜 $0.5 \mathrm{ml}$ を加 え, $37^{\circ} \mathrm{C}, 30$ 分間作用させたのち, 溶血の度合を判定し た。判定は, 感作赤血球対照, 補体対照抢よび既知陽性 血清対照において所期の結果が得られた場合，中等度以 上の溶血を示す最大稀釈倍数をもつて抗体価とした。

\section{III. 実 験 成 績}

\section{i）色素試験と補体結合反応の相関について}

色素試験と補体結合反応の成績から，陽性を示した血 清濃度の頻度を記載した成績は，第 1 表に示すとおりて あつて, この結果から, 色素試験之補体結合反応の相関

\section{第 1 表 色素試験および補体結合反応陽性例の頻度}

\begin{tabular}{c|r|r|r|r|r|r|r}
\hline C.F.T.陽性 & $1: 4$ & $1: 8$ & $1: 16$ & $1: 32$ & $1: 64$ & $1:$ & 計 \\
D.T. 陽性 & 以下 & $1: 28$ & 䚺 \\
\hline $1: 2$ 以下 & 451 & 0 & 0 & 0 & 0 & 0 & 451 \\
$1: 4$ & 23 & 5 & 1 & 0 & 0 & 0 & 29 \\
$1: 16$ & 18 & 3 & 3 & 2 & 0 & 0 & 26 \\
$1: 64$ & 1 & 1 & 2 & 1 & 1 & 0 & 6 \\
$1: 256$ & 0 & 0 & 0 & 0 & 0 & 0 & 0 \\
\hline 計 & 493 & 9 & 6 & 3 & 1 & 0 & 512 \\
\hline
\end{tabular}

係数を求めると $\mathrm{r}=+0.612(\alpha=0.01$ で有意) とな り，乙の両反応の間には有意の正相関を認めることがて きる。

しかし，乙れらの反応でトキソプラスマに対する特異 的抗体の証明に対する陽性の限界を, どの血清稀釈で示 すかについては，な扮意見の一致を認められないが， Sabin, 常松等にしたがつて，色素試験では16倍以上， 補体結合反応では 8 倍以上陽性である場合を特異的抗体 の出現による反応と判定すると, 総数 512例中, 色素試 験では 32 例 ( $6.2 \%$ ), 補体結合反応とは19例( $3.7 \%)$ が陽性であり，両反応ともに陽性を示すものは，13例 ( $2.5 \%)$ であつた。 


\section{ii）性别による陽性率について}

性別による陽性例の頻度怯，第 2 表に示すと抢りであ つて，抗体の保有率は，両反応とも性別炕よる差学示 していない。

第 2 表 性别による陽性率

\begin{tabular}{c|r|rr|rr|rr}
\hline \multirow{2}{*}{ 性別 } & 例数 & \multicolumn{2}{|c|}{ D. T. 陽性 } & \multicolumn{2}{|c|}{ C.F.T. 陽性 } & \multicolumn{2}{|c|}{ 両試験陽性 } \\
\cline { 3 - 8 } & & 例数 & $\%$ & 例数 & $\%$ & 例数 & $\%$ \\
\hline 男 & 407 & 25 & 6.1 & 16 & 3.9 & 10 & 2.4 \\
女 & 105 & 7 & 6.6 & 3 & 2.8 & 3 & 2.8 \\
\hline
\end{tabular}

\section{iii）年令别による陽性率について}

年令別による陽性率の頻度は，第 3 表に示すと抢りで あつて, 色素試験, 補体結合反応ともに年令別陽性率の 間に有意の差を認めるととはできなかつた。

第 3 表 年令别による陽性率

\begin{tabular}{l|r|rc|rr|rr}
\hline \multirow{2}{*}{ 年令 } & 例数 & D.T. & 陽性 & \multicolumn{2}{|c|}{ C.F.T. 陽性 } & \multicolumn{2}{|c|}{ 両試験陽性 } \\
\cline { 3 - 7 } & & 例数 & $\%$ & 例数 & $\%$ & 例数 & $\%$ \\
\hline $10 \sim 19$ & 67 & 4 & 5.9 & 2 & 2.9 & 2 & 2.9 \\
\hline $20 \sim 29$ & 142 & 8 & 5.6 & 6 & 4.2 & 4 & 2.8 \\
$30 \sim 39$ & 182 & 11 & 6.0 & 5 & 2.7 & 4 & 2.1 \\
$40 \sim 49$ & 81 & 6 & 7.4 & 4 & 4.9 & 2 & 2.4 \\
$50 \sim$ & 40 & 3 & 7.5 & 2 & 5.0 & 1 & 2.5 \\
\hline
\end{tabular}

さらに，性別と年令別による陽性例の頻度は第 4，5 表に示すと抬りであつて, 男女ともに年令別陽性率の発 現に有意な差を認めることができなかつた。

\section{iv）地域别陽性率について}

東京都内, 都下, 埼玉県, 神奈川県, 千葉県在住者の陽 性率を求めた。その成績梳第 6 表に示すとおりである。 東京都内 241 例虫， ほとんどすべての区にまたがつてい

第 4 表 男性の年令别陽性率

\begin{tabular}{l|r|rr|rr|rr}
\hline \multirow{2}{*}{ 年令 } & 例数 & D.T. & 陽性 & \multicolumn{2}{|c|}{ C.F.T. 陽性 } & \multicolumn{2}{|c}{ 両試験陽性 } \\
\cline { 3 - 8 } & & 例数 & $\%$ & 例数 & $\%$ & 例数 & $\%$ \\
\hline $10 \sim 19$ & 43 & 4 & 9.3 & 2 & 4.6 & 2 & 4.6 \\
\hline $20 \sim 29$ & 107 & 6 & 5.6 & 4 & 3.7 & 2 & 1.8 \\
$30 \sim 39$ & 150 & 8 & 5.3 & 4 & 2.6 & 3 & 2.0 \\
$40 \sim 49$ & 67 & 4 & 5.9 & 4 & 5.9 & 2 & 2.9 \\
$50 \sim$ & 40 & 3 & 7.5 & 2 & 5.0 & 1 & 2.5 \\
\hline 計 & 407 & 25 & 6.1 & 16 & 3.9 & 10 & 2.4 \\
\hline
\end{tabular}

第 5 表 女性の年令别陽性率

\begin{tabular}{l|r|rr|rr|rr}
\hline \multirow{2}{*}{ 年令 } & \multirow{2}{*}{ 例数 } & \multicolumn{2}{|r|}{ D.T. } & 陽性 & \multicolumn{2}{|c|}{ C.F.T. 陽性 } & \multicolumn{2}{|c|}{ 両試験陽性 } \\
\cline { 3 - 8 } & & 例数 & $\%$ & 例数 & $\%$ & 例数 & $\%$ \\
\hline $10 \sim 19$ & 24 & 0 & 0 & 0 & 0 & 0 & 0 \\
$20 \sim 29$ & 35 & 2 & 5.7 & 2 & 5.7 & 2 & 5.7 \\
$30 \sim 39$ & 32 & 3 & 9.3 & 1 & 3.1 & 1 & 3.1 \\
$40 \sim 49$ & 14 & 2 & 14.2 & 0 & 0 & 0 & 0 \\
$50 \sim$ & 0 & 0 & 0 & 0 & 0 & 0 & 0 \\
\hline 計 & 105 & 7 & 6.6 & 3 & 2.8 & 3 & 2.8 \\
\hline
\end{tabular}

るが, 特に東部, 西北部在住者が多く, 都下 112例は大 部分が三多摩在住の人々である。埼玉県 92 例はその半数 以上が西部農村地方の人々であり, 残りは川口市, 浦和 市在住者であつた。神奈川県48例の大半は川埼市, 横浜 市の人であり, 千葉県10例はすべて市川市, 船橋市の在 住者であつた。との成績について検定した結果からは, 地域別陽性率の発現には有意の差を認めることができな かつた。

\section{第 6 表 地域别陽性率}

\begin{tabular}{|c|c|c|c|c|c|c|c|}
\hline \multirow{2}{*}{ 地域名 } & \multirow{2}{*}{ 例数 } & \multicolumn{2}{|c|}{ 色素試験陽性 } & \multicolumn{2}{|c|}{$\begin{array}{l}\text { 補体結合 } \\
\text { 反応陽性 }\end{array}$} & \multicolumn{2}{|c|}{ 両試験陽性 } \\
\hline & & 例数 & $\%$ & 例数 & $\%$ & 例数 & $\%$ \\
\hline 都 内 & 241 & 13 & 5.3 & 7 & 2.9 & 5 & 2.0 \\
\hline 都 下 & 112 & 8 & 7.1 & 5 & 4.4 & 3 & 2.6 \\
\hline 埼 玉 & 92 & 8 & 8.6 & 6 & 6.5 & 4 & 4.3 \\
\hline 神奈川 & 48 & 2 & 4.1 & 1 & 2.0 & 1 & 2.0 \\
\hline 千葉 & 18 & 1 & 5.5 & 0 & 0 & 0 & 0 \\
\hline その他 & 1 & 0 & 0 & 0 & 0 & 0 & 0 \\
\hline
\end{tabular}

\section{IV. 考察}

トキソプラスマ症の診断に対して行われる色素試験お よび補体結合反応の特異性に関して行われた現在までの 報告によれば，色素試験はきわめて特異的であつて, ト キソプラスマ症以外の疾患の患者血清で 8 倍以上陽性に 出現する例は 1 例もない。そして, Sabin and Feldmann は, 10 倍以上色素試験陽性血清では 中和試験もまた陽 性であつたと報告し，また，4倍陽性程度の抗体価を示 した場合ですトキソプラスマ虫体が検出された例もあつ て, 色素試験で16倍以上の血清稀釈で陽性を示した場合 を抗体陽性として採用すると，色素試験は，きわめて高 い特異性をもつてトキソプラスマ症の診断に利用するて とができる。

一方, 補体結合反応の施行汇当つては，その抗原の作 
製法にな扣多くの問題があるょうてある。Warren and

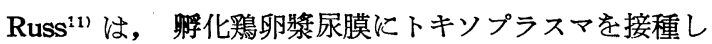
て抗原を作製する方法を推奖している。われわれがとの 实験に使用した補体結合抗原は, トキソプラスマを腹脄 内に接種したマウスの腹腔液から, 凍結融解抢よび高速 遠心法によつて作製したものである。この点に执いて， 補体結合抗原の特異性について, な怙若干の問題がある が， マウス腹胿夜方ら抗原を作製した場合でも， 8 倍以 上を陽性として判定するとかなりの特異性を示すもので あるとされている。

てのような, 色素試験あるいは補体結合反応の特異性 に関しては，上述のょうな知見が述べられているが，乙 の両者偒性である血清は, きわめて顕著な特異性を有 するものと判定するととができる。

一方, 色素試験抢よび補体結合に関与する抗体は，そ の性質がそれぞれ異なつたものであると思われ, 色素試 験抗体はトキソプラスマ感染後 $2 \sim 4$ 週間後から抗体価 が上昇しはじめ, 数年間涼涪同一の抗体価を維持し, そ の後次第に低下して, 16 32倍の抗体価が $5 \sim 10$ 数年間 持続するものといわれている。これに対して, 補体結合 抗体法感染後 1 カ月以上を経過したの与上昇し, 数年で 陰性になるといわれる12)。このような知見からみると， 色素試験陽性率は補体結合陽性率を上回ることが予測さ れ,われわれの実験結果もまたとのょうな知見に一致し ている。

このょうな概念を基礎にして, 色素試験拉よび補体結 合反応による抗体保有率について集団検査を抢てなつた 成績によると，欧米諸国での成績は，色素試験で10３0 \%以上の陽性率を示しているものが多い。本邦に怙ける 成績では, 長谷川, 常松等が, 432 例の被検材料中, 色素 試験陽性率 $7.2 \%$, 補体結合反応陽性率 $3.9 \%$, 両反応 陽性率 $2.2 \%$ という成績を報告し, 藤陵は, 56 名の被検 材料で色素試験陽性率 $6.6 \%$, 宮崎は, 48名の色素試験 で $4.2 \%$ とう陽性率を報告している ${ }^{13)}$ 。

著者等が試みた 512 名の成績では, 色素試験で 6.2 $\%$, 補体結合反応で $3.7 \%$, 両反应陽性率が $2.5 \%$ あ つて, ほぼ本邦において先人がおてなつた成績と一致す るが，欧米ての成績に比してかなり陽性率が低い。しか し，とのような陽性率は，本邦においてもトキソプラス マによる感染がかなり高率に存在しているととを示すも のである。

しかも，色素試験招上び補体結合反応に上る陽性率が ともに正相関寺示しているととは, その陽性率がどの試 験を抢こなつた場合ても, トキソプラスマによる感染に
対する有力な診断法を提供するものである。

このような陽性例について, 性別, 年令別, 地域別に 調査した試験によれば，乙れらの分類によつては有意な 差を認めるととはできなかつた。とのととは,トキソプ ラスマの感染経路についてきわめて重要な見解を示唆す るものと思われる。すなわち，少なくとも10才以上にな ると, 性, 地域に拘らず, トキソプラスマに対する抗体 の保有率に有意な差を認めえないことは, トキソプラス マによる感染が少なくとも10才以下の年令で掞てなわれ たことを推察させるものであり, トキソプラスマ感染経 路に対して, 多くの場合母体での胎盤感染が重要視され ている現在では, との成績はまたある程度, とのょうな 見解を支持するものであろう。

殊飞, 最近著者等は, 脳水腫を有した生後 48 日の新生 児が, 典型的なトキソプラスマ症で死亡した例を経験し た。しかも, 生後における感染経路はまつたく不明であ つた。しかし，その実母がトキソプラスミン反応陽性で あつたととは, トキソプラスミン反応の特異性について はまだ多くの疑問はあるが, 少なくともトキソプラスマ による感染を受けたととがあるという疑を抱かせるもの である。

したがつて，著者等がおこなつた成績にあるょうな陽 性者の中には，現在なおトキソプラスマの感染を受けて いるものがあることが予想され，トキソプラスマによる 感染が公衆衞生学的に, また, 殊に母子衞生上きわめて 重要な問題を提供するものであろう。

現在，とのトキソプラスマの感染経路についてはな拉 実験を続行中であり，前記のような例についてはさらに 詳細にその経過を追求することによつて，トキソプラス マの疫学に関してょり詳細な知見を報告したい。

\section{文献}

1) Nicolle, C. and Manceaux, L. : Arch. Inst. Pasteur, $2:$ 97, 1909.

2) Wolf, A., Cowen, D. and Paige, B. H. : Amer. J. Path., 15 : 657, 1939.

3）宮川米炊他：診療の実際， $5: 63,1954$.

4) 宮崎一郎, 平岡輝明 : 日本医事新報, 1722 号 : 38 , 1956.

5）瀬長良三郎, 田崎光 : 日本医事新報, 1673 号 : 23 , 1955.

6）松林久吉, 瀬長良三郎, 田崎光他 : 日本医事新報 1674号 : 23, 1955.

7) Sabin, A. B. and Feldmann, H. A. : Science, $108: 660,1948$.

8) Westphal, A.: Ztschr. Tropenmed, u. Parasit., $3: 72,1951$. 
9) Sabin, A. B.: Pediatrics, $4: 443,1949$.

10）長谷川秀治, 常松之典, 田中信男 : 日本細菌学雑 誌, $9: 455,1954$.

11) Warren, J. and Russ, S. B. : Proc. Soc. Exp. Biol. \& Med., 67 : 85, 1948.
12) Sabin, A. B. : J. A. M. A., 150 : 1063, 1952.

13）松林久吉: 北里 メディカルニュース, No. $34: 1$, 1957.

（受付： 1957 年 12 月 10 日) 